\title{
PENERAPAN MODEL PEMBELAJARAN CHILDREN LEARNING IN SCIENCE (CLIS) BERBANTUAN MULTIMEDIA UNTUK MENINGKATKAN KETERAMPILAN PROSES SAINS SISWA SMA PADA POKOK BAHASAN FLUIDA
}

\author{
Ali Ismail \\ STKIP Garut \\ E-mail: ai7garut@gmail.com
}

\begin{abstract}
Abstrak
Tujuan penelitian ini adalah untuk mengetahui peningkatan keterampilan proses sains fisika siswa setelah diterapkan model pembelajaran Children Learning In Science (CLIS) berbantuan multimedia pada pokok bahasan fluida statis. Penelitian ini menggunakan metode penelitian kuasi eksperimen dengan desain penelitian randomized control group Pretest-Potstest design. populasi dari penelitian ini adalah siswa kelas XI di salah satu SMA di Kabupaten Bekasi sedangkan sampel dari penelitian ini adalah di pilih dua kelas kelas XI dari keseluruhan populasi. Hasil penelitian menunjukan bahwa keterampilan proses sains setelah diterapkan model pembelajaran Children Learning In Science (CLIS) berbantuan multimedia meningkat secara signifikan dilihat dari nilai gainnya. Berdasarkan hasil analisis data diperoleh rata-rata N-gain keterampilan proses sains $57 \%$ untuk kelas eksperimen dan $49 \%$ untuk kelas kontrol,Dapat disimpulkan bahwa model pembelajaran Children Learning In Science (CLIS) berbantuan multimedia dapat lebih meningkatkan keterampilan proses sains di bandingkan dengan pembelajaran konvensional berbantuan multimedia.
\end{abstract}

Kata kunci: CLIS, Multimedia, Keterampilan Proses Sains

\section{PENDAHULUAN}

Secara rinci, fungsi dan tujuan mata pelajaran Fisika di tingkat Sekolah Menengah Atas (SMA) adalah sebagai sarana:

1) menyadarkan keindahan dan keteraturan alam untuk meningkatkan keyakinan terhadap Tuhan Yang Maha Esa,

2) memupuk sikap ilmiah, yang mencakup; jujur dan obyektif terhadap data, terbuka dalam menerima pendapat berdasarkan bukti-bukti tertentu, kritis terhadap pernyataan ilmiah, dan dapat bekerja sama dengan orang lain,

3) memberi pengalaman untuk dapat mengajukan dan menguji hipotesis melalui percobaan; merancang dan merakit instrumen percobaan, mengumpulkan, mengolah, dan menafsirkan data, menyusun laporan, serta mengkomunikasikan hasil percobaan secara tertulis dan lisan,

4) mengembangkan kemampuan berpikir analisis induktif dan deduktif dengan menggunakan konsep dan prinsip Fisika untuk menjelaskan berbagai peristiwa alam dan menyelesaikan masalah baik secara kualitatif maupun kuantitatif,

5) menguasai pengetahuan, konsep, hukumhukum dan prinsip Fisika, serta memiliki pengetahuan, keterampilan dan sikap ilmiah (Depdiknas, 2006).

Dari uraian di atas tampak bahwa penyelenggaraan mata pelajaran Fisika di SMA dimaksudkan sebagai wahana atau sarana untuk melatih para siswa agar dapat menguasai konsep dan prinsip Fisika, memiliki kecakapan ilmiah, memiliki keterampilan proses sains dan keterampilan berpikir kritis dan kreatif. Agar mata pelajaran Fisika dapat benar-benar berperan seperti demikian, maka tak dapat ditawar lagi bahwa pembelajaran Fisika harus dikonstruksi sedemikian rupa, sehingga proses pendidikan dan pelatihan berbagai kompetensi tersebut dapat benar- 
benar terjadi dalam prosesnya

Kenyataan di lapangan, proses pembelajaran Fisika dirasa masih jauh dari apa yang diharapkan. Dari pengamatan langsung peneliti di salah satu SMA di kabupaten Bekasi diperoleh bahwa sebagian besar proses pembelajaran Fisika dilaksanakan dengan menggunakan pembelajaran satu arah yang lebih menekankan pada penyampaian materi pembelajaran (metode konvensional). pada metode ini keterlibatan siswa secara aktif dalam proses belajar mengajar masih kurang. Kelemahan dalam penggunaan metode konvensional adalah pengajarannya yang terlampau matematis. Siswa cenderung dituntut untuk menghapal rumus dan penggunaan rumus tersebut tanpa memahami konsep-konsep yang melatar belakangi terbentuknya rumus tersebut, sehingga siswa pun sulit menyerap konsep-konsep fisisnya. Hal ini berdampak pada rendahnya hasil belajar fisika yang dicapai siswa. Seperti ditunjukkan oleh rata-rata nilai ulangan harian untuk materi sebelumnya hanya 5,8 .

Selain itu pembelajaran secara konvensional ini kurang dapat menumbuhkan keterampilan proses sains siswa, karena pembelajaran difokuskan pada aspek kognitif, sedangkan aspek psikomotorik dan aspek afektif kurang diperhatikan. Hal ini menyebabkan kesempatan siswa untuk terlibat dalam proses belajar dan kesempatan untuk mengembangkan diri berkurang.

Salah satu pembelajaran yang dipandang dapat membantu dan memfasilitasi untuk memudahkan siswa dalam berlatih mengembangkan keterampilan proses sains adalah model pembelajaran children learning in science (CLIS). Model pembelajaran CLIS adalah kerangka berpikir untuk menciptakan lingkungan yang memungkinkan terjadinya kegiatan belajar mengajar yang melibatkan siswa dalam kegiatan pengamatan dan percobaan dengan menggunakan Lembar Kerja Siswa (LKS).

Pada saat ini kita juga sedang memasuki era informasi. Teknologi dan komunikasi (TIK) yang terus berkembang dan cenderung akan terus mempengaruhi segenap kehidupan manusia. Perkembangan di bidang teknologi informasi dan komunikasi yang sangat cepat ini berpengaruh juga terhadap pribadi, aktivitas, kehidupan ataupun cara berpikir. Perkembangan ini perlu juga dikenalkan pada siswa agar mereka mempunyai bekal pengetahuan dan pengalaman untuk menerapkan dan menggunakan TIK dalam kegiatan belajar mengajar. Dalam proses pembelajaran saat ini banyak dikembangkan media-media pembelajaran berbasis komputer, salah satunya pembuatan dan pengembangan software dalam media pembelajaran

Perkembangan TIK ini memungkinkan dihasilkannnya berbagai multimedia dalam pembelajaran yang dapat memudahkan dan membangkitkan motivasi belajar siswa dalam mempelajari konsep Fisika. Menurut beberapa penelitian diantaranya yang di ungkapkan Wiendartun, Taufik dan Hery (2007) mengungkapkan bahwa, pembelajaran berbasis multimedia dapat meningkatkan hasil belajar siswa.

Berdasarkan pemaparan di atas, maka penulis memandang perlu untuk melakukan sebuah penelitian mengenai "penerapan model pembelajaran children learning in science (CLIS) berbantuan multimedia untuk meningkatkan keterampilan proses sains siswa pada pokok bahasan fluida statis".

Berdasarkan latar belakang masalah yang telah diuraikan di atas, maka permasalahan dalam penelitian ini dapat dirumuskan dalam bentuk pertanyaan sebagai berikut: "apakah model pembelajaran children learning in science (CLIS) berbantuan multimedia dapat lebih meningkatkan keterampilan proses sains, siswa dibandingkan pembelajaran konvensional berbantuan multimedia?".

\section{METODE/EKSPERIMEN}

Penelitian ini menggunakan metode kuasi eksperimen (eksperimen semu) dan deskriptif. Metode eksperimen semu digunakan untuk mengetahui perbandingan peningkatan keterampilan proses sains antara siswa yang mendapatkan pembelajaran dengan model pembelajaran children learning in science 
Penerapan Model Pembelajaran Children Learning In Science (CLIS) Berbantuan 85

Multimedia untuk Meningkatkan Keterampilan Proses Sains Siswa SMA pada Pokok

Bahasan Fluida

Ali Ismail

(CLIS) berbantuan multimedia dan yang mendapatkan pembelajaran konvensional berbantuan multimedia. Metode deskriptif digunakan untuk mengetahui gambaran tentang tanggapan siswa terhadap model pembelajaran CLIS berbantuan multimedia yang diterapkan..

Desain eksperimen yang digunakan adalah "The randomized Pretest-Posttest control group design" dimana penentuan kelas kontrol dan eksperimen dilakukan secara acak perkelas. Eksperimen dilakukan dengan memberikan perlakuan pembelajaran dengan model pembelajaran CLIS berbantuan multimedia pada kelompok eksperimen dan pembelajaran konvensional berbantuan multimedia pada kelompok kontrol.

Subyek penelitian ini adalah siswa kelas XI Semester genap di salah satu SMA Negeri yang berada di kabupaten Bekasi Provinsi Jawa Barat pada tahun pelajaran 2010/2011. Kelas XI IPA terdiri dari lima kelas yang masingmasing kelas terdiri atas \pm 32 orang siswa. Teknik pengambilan sampel adalah dengan cara cluster random sampling. Sebagai sampel penelitian dipilih dua kelas secara acak dari lima kelas yang memiliki kemampuan yang setara tanpa mengacak siswa tiap kelasnya. Pengelompokkan sampel terdiri dari satu kelas eksperimen dan satu kelas kontrol..

Analisis instrumen penelitian dilakukan untuk mengetahui kelayakan perangkat tes keterampilan proses sains. Analisis yang dilakukan meliputi analisis uji validitas, tingkat kesukaran, daya pembeda dan reliabilitas instrumen. Proses pengujian dilakukan dengan menggunakan software anates versi 4 dan manual

\section{HASIL DAN PEMBAHASAN}

\section{HASIL}

Kemampuan keterampilan proses sains terhadap materi fluida statis diukur dengan tes pilihan ganda sebanyak 15 soal. Data Perbandingan nilai rata-rata tes awal, tes akhir dan gain yang dinormalisasi (dalam persen) antara kelas eksperimen dan kelas kontrol ditunjukkan pada Gambar 1.

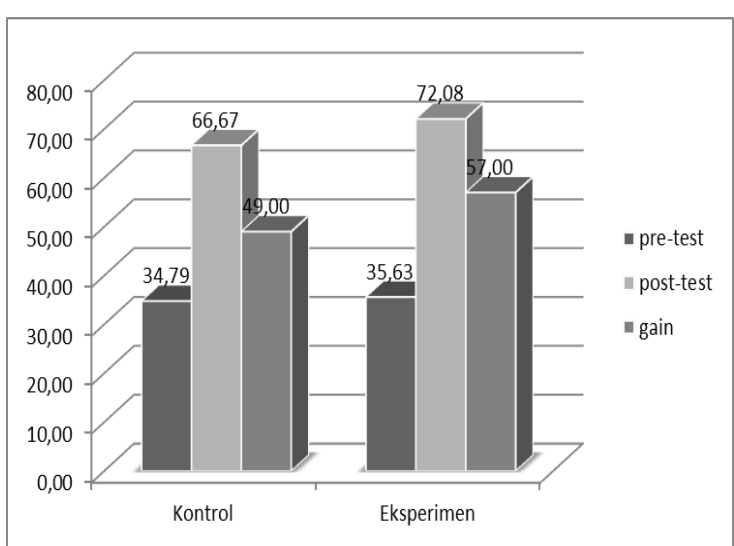

Gambar 1. Perbandingan Nilai Pre test, Post test dan Gain ternormalisasi

Berdasarkan Gambar 1 diperoleh bahwa nilai rata-rata gain yang dinormalisasi untuk kelas eksperimen ialah 0,57 dengan kategori sedang dan nilai rata-rata gain yang dinormalisasi untuk kelas kontrol ialah 0,49 dengan kategori sedang. Perbandingan nilai ini secara langsung menunjukkan bahwa penggunaan model pembelajaran Children Learning in Science (clis) berbantuan multimedia dapat lebih efektif meningkatkan keterampilan proses sains siswa pada konsep fluida statis dibandingkan dengan pembelajaran konvensional berbantuan multimedia.

Konsep fluida statis yang dibahas dalam penelitian ini terdiri dari tiga label konsep (sub pokok bahasan) yaitu tekanan hidrostatis, hukum pascal dan hukum archimedes. Dari hasil penelitian menunjukkan prosentase nilai rata-rata $\mathrm{N}$-gain subkonsep dari materi fluida statis untuk kelas eksperimen lebih tinggi dari pada kelas kontrol.

Perbandingan $\mathrm{N}$-gain untuk setiap label konsep ditunjukkan oleh diagram batang pada Gambar 2 di bawah ini. 


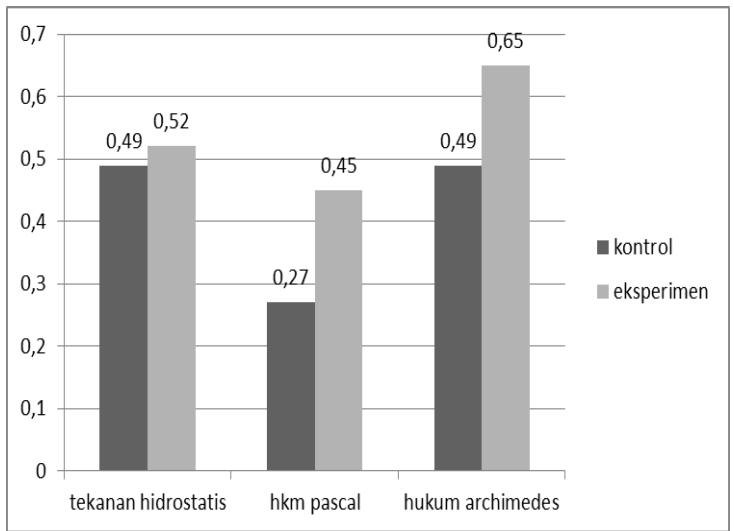

Gambar 2. Perbandingan N-Gain untuk Setiap Label Konsep antara Kelas Eksperimen dan Kelas Kontrol

Gambar 2 menunjukkan bahwa N-Gain keterampilan proses sains berdasarkan label konsep untuk kelas eksperimen tertinggi pada label konsep hukum archimedes sebesar 0,65 dengan kategori sedang dan terendah pada label konsep hukum pascal sebesar 0,45 dengan kategori rendah. Sementara pada kelas kontrol tertinggi pada label konsep hukum archimedes sebesar 0,61 dengan kategori sedang dan terendah pada label konsep hukum pascal sebesar 0,27 dengan kategori rendah. Dengan demikian persentase dan $\mathrm{N}$-gain pencapaian keterampilan proses sain untuk setiap label konsep fluida statis kelas eksperimen lebih tinggi dibandingkan kelas kontrol.

Peningkatan keterampilan proses sains dapat dikelompokkan untuk setiap tipe keterampilan yaitu, keterampilan mengamati, interpretasi, klasifikasi, prediksi, aplikasi konsep, merencanakan percobaan dan mengkomunikasikan.

Nilai rata-rata gain yang dinormalisasi untuk setiap tipe keterampilan proses sains untuk kelas eksperimen dan kelas kontrol diperlihatkan oleh Gambar 3 di bawah ini .

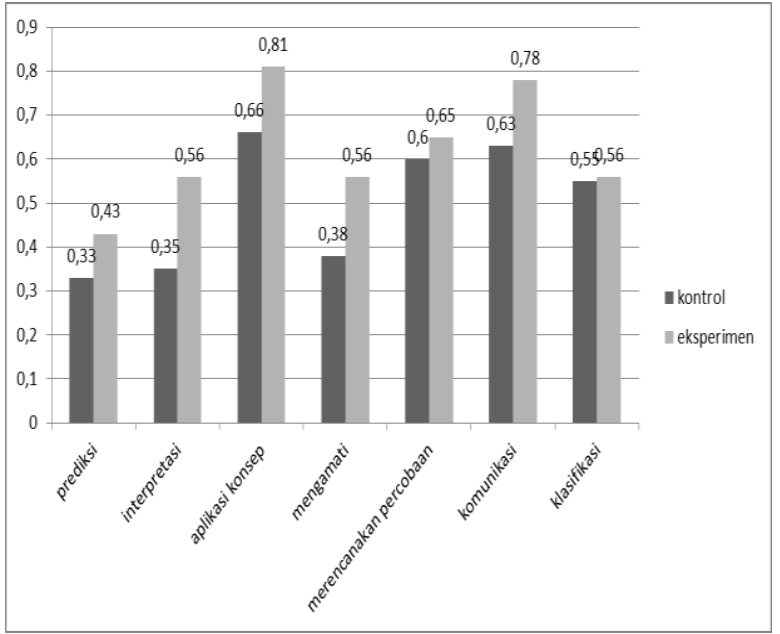

Gambar 3. Perbandingan Nilai Rata-Rata Gain yang Dinormalisasi Per Tipe Keterampilan

Proses Sains

Berdasarkan Gambar 3 perolehan ratarata gain yang dinormalisasi KPS siswa untuk setiap aspek KPS pada pembelajaran dengan model CLIS berbantuan multimedia lebih tinggi dibandingkan dengan pembelajaran konvensional berbantuan multimedia.

\section{PEMBAHASAN}

Berdasarkan hasil analisis data pretes keterampilan proses sains pada konsep Fluida statis, diketahui bahwa skor rata-rata kelas kontrol cenderung sama dengan kelas eksperimen sebelum penerapan model kegiatan laboratorium. Dengan demikian dapat disimpulkan bahwa kedua kelas memiliki kemampuan awal yang sama.

Kedua kelompok kelas diberi perlakuan pembelajaran yang berbeda yaitu kelas kontrol menggunakan model pembelajaran konvensional sedangkan kelas eksperimen menggunakan model pembelajaran CLIS. Untuk mengetahui peningkatan keterampilan proses sains siswa maka dilakukan posttest dan hasilnya dianalisis.

Berdasarkan hasil analisis data, siswa yang mendapatkan pembelajaran dengan model pembelajaran CLIS secara keseluruhan menunjukkan keterampilan proses sainsnya lebih baik dibandingkan dengan siswa yang mendapatkan pembelajaran dengan model pembelajaran konvensional. Tingginya perolehan skor posttest dan gain yang dinormalisasi kelas eksperimen disebabkan 
karena model pembelajaran CLIS mengarahkan siswa pada berbagai aktifitas seperti mengamati, meramalkan, menafsirkan, menerapkan konsep, merencanakan eksperimen dan mengkomunikasikan.

Dahar (1989) menyatakan bila seorang anak selama belajar sains hanya diberi informasi tentang sains yang sudah ada dengan cara mendengarkan penjelasan guru, maka sains itu sendiri akan berhenti berkembang. Sains bukan hanya pengetahuan yang terdiri dari fakta-fakta, prinsip-prinsip, konsep-konsep dan teori-teori yang dikenal dengan produk sains, melainkan juga keterampilan-keterampilan dan sikap-sikap yang diperlukan untuk mencapai produk sains yang dikenal dengan proses sains.

Hal tersebut sejalan dengan pendapat Rustaman (1997) mendefinisikan keterampilan proses sains sebagai keterampilan yang diperlukan untuk memperoleh, mengembangkan dan menerapkan konsepkonsep, prinsip-prinsip, hukum-hukum dan teori sains baik berupa keterampilan mental, keterampilan fisik maupun keterampilan sosial. Keterapilan proses sains ini dapat ditingkatkan dengan model pembelajaran CLIS.

Berdasarkan hasil analisis data diperoleh bahwa nilai rata-rata gain yang dinormalisasi untuk kelas eksperimen ialah 0,57 dengan kategori sedang dan nilai rata-rata gain yang dinormalisasi untuk kelas kontrol ialah 0,49 dengan kategori sedang. Perbandingan nilai ini secara langsung menunjukkan bahwa penggunaan model pembelajaran Children Learning in Science (clis) berbantuan multimedia dapat lebih efektif meningkatkan keterampilan proses sains siswa pada konsep fluida statis dibandingkan dengan pembelajaran konvensional berbantuan multimedia.

\section{PENUTUP}

Berdasarkan data dan analisis hasil penelitian yang telah dilakukan tentang model pembelajaran children learning in science (CLIS) pada pembelajaran fluida statis untuk mengembangkan keterampilan proses sains konsep dapat disimpulkan bahwa: Model pembelajaran CLIS berbantuan multimedia secara signifikan dapat lebih meningkatkan keterampilan proses sains siswa dibandingkan dengan model pembelajaran konvensional berbantuan multimedia.

\section{DAFTAR PUSTAKA}

Dahar, R Wilis. (1989). Teori-teori Belajar. Jakarta: Erlangga.

Depdiknas. (2006). Kurikulum Tingkat Satuan Pendidikan Sekolah Menengah Atas. Jakarta: Depdiknas.

Driver. R. (1988). "changing conceptions". Journal research in education 161-196.

Rustaman, N dan Rustaman, A. (1997), PokokPokok Pengajaran Biologi dan Kurikulum 1994. Jakarta: Pusbuk Depdikbud.

Wiendartun, Taufik dan Hery (2007). "Pengaruh Pembelajaran Berbasis Multimedia Terhadap Hasil Belajar Fisika" bandung : Proceeding of The First International Seminar on Science Education. 